\title{
Calcium Channel Types with Distinct Presynaptic Localization Couple Differentially to Transmitter Release in Single Calyx-Type Synapses
}

\author{
Ling-Gang Wu, ${ }^{1}$ Ruth E. Westenbroek, ${ }^{2}$ J. Gerard G. Borst, ${ }^{1}$ William A. Catterall,, ${ }^{2}$ and Bert Sakmann ${ }^{1}$ \\ ${ }^{1}$ Abteilung Zellphysiologie, Max-Planck-Institut für medizinische Forschung, D-69120 Heidelberg, Germany, and \\ 2Department of Pharmacology, University of Washington, Seattle, Washington 98195-7280
}

We studied how $\mathrm{Ca}^{2+}$ influx through different subtypes of $\mathrm{Ca}^{2+}$ channels couples to release at a calyx-type terminal in the rat medial nucleus of the trapezoid body by simultaneously measuring the presynaptic $\mathrm{Ca}^{2+}$ influx evoked by a single action potential and the EPSC. Application of subtype-specific toxins showed that $\mathrm{Ca}^{2+}$ channels of the P/Q-, N-, and R-type controlled glutamate release at a single terminal. The $\mathrm{Ca}^{2+}$ influx through the P/Q-type channels triggered release more effectively than $\mathrm{Ca}^{2+}$ influx through $\mathrm{N}$ - or R-type channels. We investigated mechanisms that contributed to these differences in effectiveness. Electrophysiological experiments suggested that individual release sites were controlled by all three subtypes of $\mathrm{Ca}^{2+}$ channels. Immunocytochemical staining indi- cated, however, that a substantial fraction of $\mathrm{N}$ - and R-type channels was located distant from release sites. Although these distant channels contributed to the $\mathrm{Ca}^{2+}$ influx into the terminal, they may not contribute to release. Taken together, the results suggest that the $\mathrm{Ca}^{2+}$ influx into the calyx via $\mathrm{N}$ - and $\mathrm{R}$-type channels triggers release less effectively than that via $\mathrm{P} / \mathrm{Q}$-type because a substantial fraction of the $\mathrm{N}$ - and R-type channels in the calyx is localized distant from release sites.

Key words: $\mathrm{Ca}^{2+}$ channels; presynaptic; calyx of Held; voltage clamp; antibody; immunocytochemistry; P-type $\mathrm{Ca}^{2+}$ channels; $\mathrm{N}$-type $\mathrm{Ca}^{2+}$ channels; $\mathrm{R}$-type $\mathrm{Ca}^{2+}$ channels; synaptotagmin; fura-2; rat
Fast neurotransmitter release depends strongly on the extracellular $\mathrm{Ca}^{2+}$ concentration (Dodge and Rahamimoff, 1967; Katz, 1969). By changing the $\mathrm{Ca}^{2+}$ influx through all presynaptic $\mathrm{Ca}^{2+}$ channels, a quantitative estimate of the relation between intracellular $\mathrm{Ca}^{2+}$ concentration at the release sites $\left(\left[\mathrm{Ca}_{\text {site }}\right]\right)$ and release may be obtained. This relation is often approximated by:

$$
\text { Release } \propto\left[\mathrm{Ca}_{\text {site }}\right]^{n}
$$

where $n$ is between 3 and 4 (for review, see Wu and Saggau, 1997).

$\mathrm{Ca}^{2+}$ channel subtypes have been classified as T-, L-, N-, P-, $\mathrm{Q}-$, and R-type on the basis of their different pharmacological and biophysical properties (Dunlap et al., 1995). Different $\mathrm{Ca}^{2+}$ channel subtypes have different pore-forming $\alpha_{1}$ subunits. The $\alpha_{1 \mathrm{~A}}$ subunits form P/Q-type, $\alpha_{1 \mathrm{~B}}$ subunits form N-type, and $\alpha_{1 \mathrm{E}}$ subunits form R-type $\mathrm{Ca}^{2+}$ channels (Dunlap et al., 1995). Most of these $\mathrm{Ca}^{2+}$ channel subtypes can be blocked by specific toxins. These toxins have a high affinity for $\mathrm{Ca}^{2+}$ channels and presumably unbind from $\mathrm{Ca}^{2+}$ channels much slower than inorganic $\mathrm{Ca}^{2+}$ channel blockers such as $\mathrm{Cd}^{2+}$ (Yoshikami et al., 1989; Mintz et al., 1995). The toxins can be used to measure the contribution of the different channel subtypes to transmitter release. If both the volume-averaged presynaptic $\mathrm{Ca}^{2+}$ concentra-

\footnotetext{
Received Aug. 19, 1998; revised Oct. 28, 1998; accepted Oct. 29, 1998.

L.G.W. was supported by the Alexander von Humboldt Foundation and Human Frontier Science Program. J.G.G.B. was supported by a Training and Mobility of Researchers fellowship. R.E.W. and W.A.C. were supported by National Institutes of Health Grant NS22625. We thank Drs. Erwin Neher and Bernard Katz for helpful comments on this manuscript.

Correspondence should be addressed to Dr. Ling-Gang Wu, Abteilung Zellphysiologie, Max-Planck-Institut für medizinische Forschung, Jahnstrasse 29, D-69120 Heidelberg, Germany.

Copyright (C) 1999 Society for Neuroscience $\quad 0270-6474 / 99 / 190726-11 \$ 05.00 / 0$
}

tion $\left(\left[\mathrm{Ca}_{\text {terminal }}\right]\right)$ and release are monitored in experiments in which a $\mathrm{Ca}^{2+}$ channel subtype is specifically blocked, an estimate for the effectiveness $(m)$ of that subtype in controlling transmitter release (Wu and Saggau, 1997) can be obtained from:

$$
\text { Release } \propto\left[\mathrm{Ca}_{\text {terminal }}\right]^{m}
$$

Relations 1 and 2 have a similar format but different physical meanings. The parameter $m$ is defined here as a measure of how effectively $\mathrm{Ca}^{2+}$ influx into a terminal via a particular subtype of $\mathrm{Ca}^{2+}$ channels triggers release. The parameter $n$, most likely, is a measure of the cooperative binding of intracellular $\mathrm{Ca}^{2+}$ to the $\mathrm{Ca}^{2+}$ sensor at a release site (Dodge and Rahamimoff, 1967).

The values of $m$ for different subtypes of $\mathrm{Ca}^{2+}$ channels may differ in single terminals and can be different from $n$ (Mintz et al., 1995; Wu et al., 1998). These differences may provide information about the spatial organization of release sites and $\mathrm{Ca}^{2+}$ channels. For example, if each release site is controlled by the $\mathrm{Ca}^{2+}$ domain near a single open $\mathrm{Ca}^{2+}$ channel, reducing the number of active $\mathrm{Ca}^{2+}$ channels by applying a channel subtype-specific toxin will cause a linear reduction of release, resulting in $m=1$ (Yoshikami et al., 1989; Augustine et al., 1991). However, evidence suggests that multiple $\mathrm{Ca}^{2+}$ channels contribute to release in a single release site in many central synapses (Mintz et al., 1995; Borst and Sakmann, 1996, 1999; Wu and Saggau, 1997). When a release site is controlled by multiple $\mathrm{Ca}^{2+}$ channels, several mechanisms may be responsible for different values of $m$. As an example, assume that two subtypes of $\mathrm{Ca}^{2+}$ channels (types 1 and 2), with each contributing one half of the total $\mathrm{Ca}^{2+}$ influx, are present in a terminal with two release sites. If the channel subtypes are completely segregated, with one subtype being present exclusively on the first release site and the other one only on the 
second, blocking one subtype of $\mathrm{Ca}^{2+}$ channels will reduce both $\mathrm{Ca}^{2+}$ influx and release by half, meaning that $m$ for both subtypes would be only 1 . The value $m$ thus depends on the distribution of a subtype of $\mathrm{Ca}^{2+}$ channels at different release sites (Mintz et al., 1995; Reid et al., 1998; see Appendix). An alternative mechanism applies when type $1 \mathrm{Ca}^{2+}$ channels are located so far from the release sites that they do not contribute to release. In that case, $m$ is zero for type 1 and infinity for type 2 channels when these channel types are blocked. If type $1 \mathrm{Ca}^{2+}$ channels are, on average, more distantly located from the release sites than type 2 channels, $m$ for type 1 will be lower than for type 2. Thus, $m$ also depends on the distance between the channel and the release sites (Artalejo et al., 1994).

Here, we investigated mechanisms underlying differences in $m$ of $\mathrm{Ca}^{2+}$ channel subtypes at the medial nucleus of the trapezoid body (MNTB) (Wu et al., 1998). In contrast to other studies that determined the effectiveness of a $\mathrm{Ca}^{2+}$ channel subtype from a population of synapses (Wu and Saggau, 1994; Mintz et al., 1995), we measured $m$ by simultaneously recording the presynaptic $\mathrm{Ca}^{2+}$ influx and release at single synapses (Wu et al., 1998). Because of the large size of the presynaptic calyx, the subcellular distribution of different subtypes of $\mathrm{Ca}^{2+}$ channels can be studied with immunocytochemical techniques (Westenbroek et al., 1992, 1995; Yokoyama et al., 1995). We found that transmitter release from the calyx was controlled by $\mathrm{P} / \mathrm{Q}-, \mathrm{N}$-, and R-type channels. However, the effectiveness of $\mathrm{P} / \mathrm{Q}$-type $\mathrm{Ca}^{2+}$ channels was higher than of $\mathrm{N}$ - and R-type channels. This difference was most likely caused by a larger fraction of $\mathrm{N}$ - and R-type than P/Q-type channels being located distant from release sites.

\section{MATERIALS AND METHODS}

Slices were cut from the brainstems of 8- to 10-d-old Wistar rats, transferred to a recording chamber and perfused at room temperature $\left(23-24^{\circ} \mathrm{C}\right)$ with a solution containing (in $\mathrm{mM}$ ): $125 \mathrm{NaCl}, 2.5 \mathrm{KCl}, 1$ $\mathrm{MgCl}_{2}, 2 \mathrm{CaCl}_{2}, 25$ dextrose, $1.25 \mathrm{NaH}_{2} \mathrm{PO}_{4}, 0.4$ ascorbic acid, 3 myo-inositol, 2 sodium pyruvate, and $25 \mathrm{NaHCO}_{3}, \mathrm{pH} 7.4$, when bubbled with $95 \% \mathrm{O}_{2}$ and $5 \% \mathrm{CO}_{2}$ (Borst et al., 1995). Whole-cell current-clamp recordings from terminals were made with an AxoClamp-2B (Axon Instruments, Foster City, CA) amplifier and glass pipettes (8-12 M $\Omega$ ) containing (in mM): 115 potassium gluconate, $20 \mathrm{KCl}, 4 \mathrm{MgATP}, 10$ $\mathrm{Na}_{2}$-phosphocreatine, 0.3 GTP, 10 HEPES, and 0.05 fura-2 (Molecular Probes, Eugene, OR), $\mathrm{pH}$ 7.2, adjusted with $\mathrm{KOH}$. Apart from serving as $\mathrm{a} \mathrm{Ca}^{2+}$ indicator, the fura-2 fluorescence was also used at the end of the experiment to confirm the presynaptic origin of the recording. Wholecell voltage-clamp recordings from postsynaptic cells were made with an Axopatch-200A amplifier. Pipettes had a resistance of 1.5-2 M $\Omega$ and were filled with the same solution as the pipettes used for presynaptic recordings, except they contained $0.5 \mathrm{~mm}$ EGTA instead of $50 \mu \mathrm{M}$ fura- 2 . Series resistance in postsynaptic recordings $(<15 \mathrm{M} \Omega)$ was always compensated to $98 \%$ (lag, $10 \mu \mathrm{sec}$ ).

Whole-cell $\mathrm{Ca}^{2+}$ current recordings from terminals were made with an Axopatch-200A amplifier (Axon Instruments) and pipettes with a resistance of 4-6 M $\Omega$ that contained the same intracellular solution as used for current-clamp recordings except that potassium was replaced by cesium. In addition, $1 \mu \mathrm{M}$ tetrodotoxin and $0.1 \mathrm{~mm}$ 3,4-diaminopyridine (Sigma, St. Louis, MO) were added to the extracellular solution, and 20 mM NaCl was replaced with $20 \mathrm{~mm}$ tetraethylammonium chloride (Sigma) to block sodium and potassium channels (Borst et al., 1995). Series resistance $(<35 \mathrm{M} \Omega)$ compensation was set at $90 \%$ with a lag of $10 \mu \mathrm{sec}$, and prediction was set at $60 \%$. Subtraction of the passive response was by the $\mathrm{P} /-5$ method. Terminals with a capacitance of $<35 \mathrm{pF}$ were selected to avoid long axons (Borst and Sakmann, 1998). For the waveform command, we used the presynaptic action potential displayed in Figure $2 A$ of Borst et al., 1995, interpolated to $20 \mu \mathrm{sec}$ per point with a cubic spline. Potentials were corrected for a liquid junction potential of -11 $\mathrm{mV}$ between the extracellular and the pipette solution. Holding potential in voltage-clamp experiments was $-80 \mathrm{mV}$. Potentials or currents were low-pass filtered at $2-5 \mathrm{kHz}$ and digitized at $20-50 \mathrm{kHz}$ with a 16 -bit analog-to-digital converter (Instrutech, Great Neck, NY).

The optical recording system comprised an upright epifluorescence microscope (Axioskop; Achroplan 40×, NA 0.75, Zeiss), equipped with a polychromatic illumination system (TILL Photonics, Munich, Germany), a dichroic mirror (400 nm), a long-pass (415 nm) emission filter, and two photodiodes at the image plane for signal and background subtraction, respectively. Excitation light was coupled to the microscope via a light guide. Fura- 2 measurements of $\mathrm{Ca}^{2+}$ concentration were made by forming ratios between two continuous recordings (100-500 msec) of fluorescence (after background subtraction) at two excitation wavelengths $(357$ and $380 \mathrm{~nm}$ ) with an interval of $\sim 10 \mathrm{msec}$ (Grynkiewicz et al., 1985). Calibration parameters were obtained from in vivo calibrations as described in Helmchen et al. (1997). Fluorescence signals recorded by the photodiode (Hamamatsu) were filtered at $30 \mathrm{~Hz}$ (8-pole Bessel filter). Since the $\mathrm{Ca}^{2+}$ transient evoked by an action potential decays with a time constant $>400 \mathrm{msec}$ in the presence of $50 \mu \mathrm{M}$ fura-2 (Helmchen et al., 1997), filtering this transient at $30 \mathrm{~Hz}$ did not affect the measurement of its amplitude. Fura-2 was far from saturation during single action potentials, because (1) the peak $\mathrm{Ca}^{2+}$ concentrations evoked by single action potentials were usually less than the $K_{\mathrm{d}}(273 \mathrm{~nm})$ of fura-2 measured in vivo (Helmchen et al., 1997), and (2) paired-pulse action potential stimulation (interval: $50 \mathrm{msec}$ ) caused approximately the same $\mathrm{Ca}^{2+}$ influx for each action potential (data not shown). The large $\mathrm{Ca}^{2+}$ influx during a presynaptic action potential (Borst and Sakmann, 1996) and the favorable surface-to-volume ratio of the terminal permitted us to resolve $\mathrm{Ca}^{2+}$ influx during single action potentials, and to measure the relation between release and presynaptic $\mathrm{Ca}^{2+}$ influx at the level of a single synapse.

For simultaneous presynaptic and postsynaptic recordings, only synapses in which the postsynaptic cells discharged an action potential in response to afferent stimulation were selected for recording (Borst et al., 1995). Single afferent stimuli were applied via a bipolar electrode (3-30 $\mathrm{V}, 100 \mu \mathrm{sec})$ placed at the midline of the trapezoid body. Stimulation interval was 20-30 sec, which is sufficiently long to avoid synaptic depression (Von Gersdorff et al., 1997).

The degree of reduction in the presynaptic $\mathrm{Ca}^{2+}$ influx and release during application of a toxin was evaluated after its effect reached equilibrium. Data were expressed as mean \pm SEM. $\omega$-Agatoxin-IVA (Aga) was a gift from Dr. N. A. Saccomano, Pfizer, Groton, CT; $\omega$-conotoxin-GVIA (Ctx) was purchased from Bachem (Bubendorf, Germany) and Research Biochemicals (Natick, MA); and $\omega$-conotoxinMVIIC was from Research Biochemicals. The toxins were applied in the presence of $0.1 \mathrm{mg} / \mathrm{ml}$ cytochrome $\mathrm{C}$ to block nonspecific binding sites. Cytochrome $\mathrm{C}$ did not significantly affect the $\operatorname{EPSC}(\mathrm{n}=16 ; p>0.5)$, or $\Delta\left[\mathrm{Ca}^{2+}\right](\mathrm{n}=3 ; p>0.5$; paired $t$ test $)$.

For the immunocytochemical studies, 10-d-old Wistar rats were anesthetized with Nembutal and then intracardially perfused with $4 \%$ paraformaldehyde in $\mathrm{PB}$ (0.1 M sodium phosphate, $\mathrm{pH} 7.4$ ) containing $0.34 \%$ L-lysine and $0.05 \%$ sodium $m$-periodate (McLean and Nakane, 1974). The brains were removed immediately from the cranium, post-fixed for 2 $\mathrm{hr}$, and then cryoprotected by sinking in $10(\mathrm{w} / \mathrm{v})$ and $30 \%(\mathrm{w} / \mathrm{v})$ sucrose in $\mathrm{PB}$ at $4^{\circ} \mathrm{C}$ for $72 \mathrm{hr}$. Coronal sections $(40 \mu \mathrm{m})$ were cut on a sliding microtome and processed for immunocytochemistry using the avidinbiotin complex method.

Free-floating sections were processed for immunocytochemistry by rinsing the tissue in $0.1 \mathrm{M}$ Tris buffer (TB) for $15 \mathrm{~min}, 0.1 \mathrm{M}$ Tris-buffered saline (TBS) for $15 \mathrm{~min}$, blocking in $2 \%$ avidin in TBS for $30 \mathrm{~min}$, rinsing in TBS for $30 \mathrm{~min}$, blocking in $2 \%$ biotin in TBS for $30 \mathrm{~min}$, and rinsing in TBS for $30 \mathrm{~min}$. The tissue was then incubated in affinity-purified anti-peptide antibody anti-CNA5 (against $\alpha_{1 \mathrm{~A}}$ subunit, diluted 1:15), anti-CNB2 (against $\alpha_{1 \mathrm{~B}}$ subunit, diluted 1:15), or anti-CNE2 (against $\alpha_{1 \mathrm{E}}$ subunit, diluted 1:15) simultaneously with anti-synaptotagmin (diluted 1:200) for $1 \mathrm{hr}$ at room temperature followed by $36 \mathrm{hr}$ at $4^{\circ} \mathrm{C}$. All antibodies were diluted in $0.1 \mathrm{M}$ TBS containing $0.075 \%$ Triton X-100 and $1 \%$ normal goat serum. The sections were rinsed for $1 \mathrm{hr}$ in TBS and then incubated in a solution containing biotinylated goat anti-rabbit IgG (for anti-CNA5, anti-CNB2, or anti-CNE2 antibodies) diluted 1:300 and anti-mouse IgG Texas Red (for anti-synaptotagmin antibody) diluted 1:200 for $1 \mathrm{hr}$ at $37^{\circ} \mathrm{C}$. Tissue sections were then rinsed in TBS for $1 \mathrm{hr}$ and incubated in avidin D-fluorescein (diluted 1:300) and anti-mouse IgG Texas Red (diluted 1:200) for $1 \mathrm{hr}$ at $37^{\circ} \mathrm{C}$, rinsed in TBS for $10 \mathrm{~min}$, rinsed in TB for $20 \mathrm{~min}$, mounted onto gelatin-coated slides, and then coverslipped using Vectashield. 
A

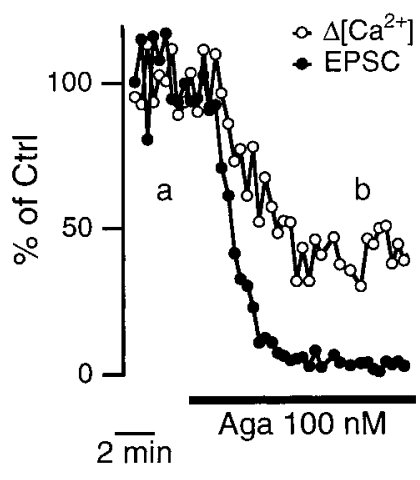

C

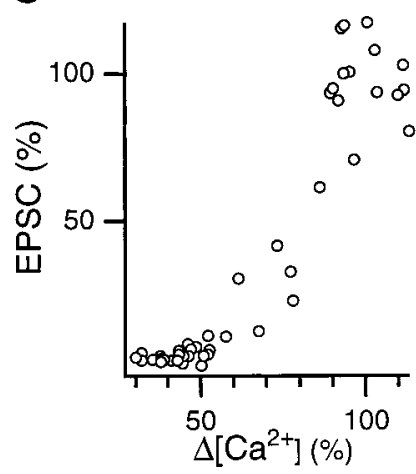

B
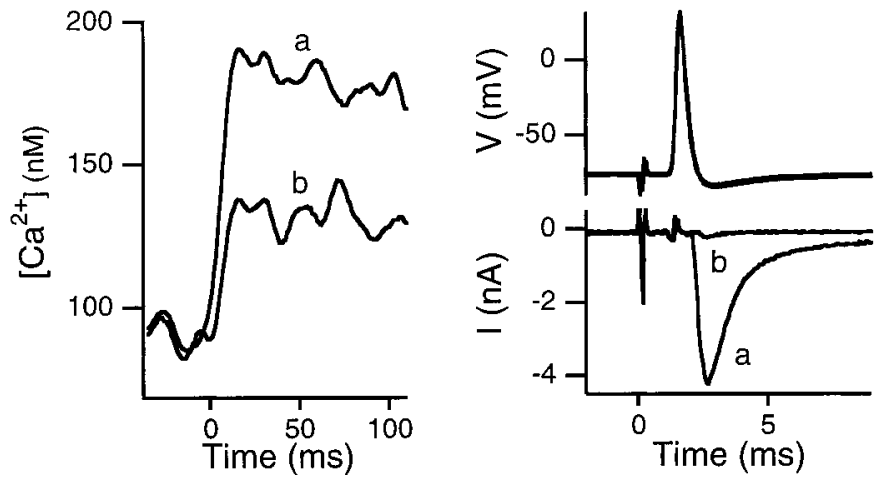

$\mathrm{D}$

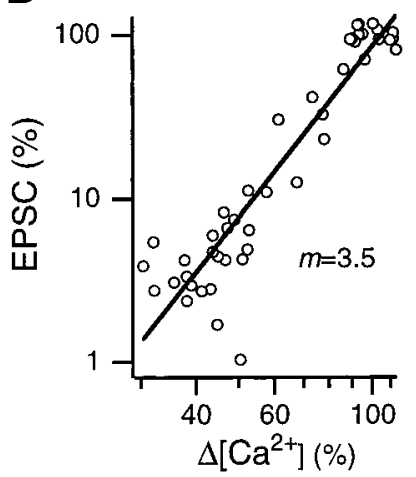

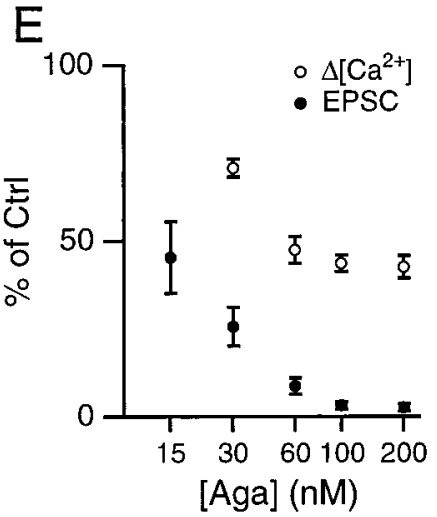

Figure 1. Effect of Aga on presynaptic $\Delta\left[\mathrm{Ca}^{2+}\right]$ and EPSC. $A$, Aga $(100 \mathrm{~nm})$ reduced concurrently both the $\Delta\left[\mathrm{Ca}^{2+}\right]$ and the EPSC evoked by single presynaptic action potentials. The values of $\Delta\left[\mathrm{Ca}^{2+}\right]$ and of the EPSCs are given relative to their respective average values before application of the toxin. $B$, Sample traces of the presynaptic $\mathrm{Ca}^{2+}$ influx (left), the presynaptic action potential (top right), and the EPSC (bottom right) before $(a)$ and after ( $b$, as indicated in $A$ ) Aga application. The stimulus was given at time 0. Each trace was taken from a single sweep (same for all the following figures). $C, D$, EPSCs plotted against the $\Delta\left[\mathrm{Ca}^{2+}\right]$ from panel $A$ on linear $(C)$ and double logarithmic $(D)$ scales. The slope of the linear regression line in $D$ was 3.5. $E$, Summary of the dose-dependent effect of Aga on the $\Delta\left[\mathrm{Ca}^{2+}\right]$ and the EPSC (each value was obtained from three to nine cells).

The immunofluorescent staining was viewed using a Bio-Rad (Hercules, CA) MRC 600 microscope located in the imaging facility of the W. M. Keck Center for Research in Neural Signaling at the University of Washington. The thickness of optical sections was typically $1 \mu \mathrm{m}$. Tissue sections double-labeled for $\mathrm{N}$-type and $\mathrm{P} / \mathrm{Q}$-type $\mathrm{Ca}^{2+}$ channels were treated the same as above but were incubated in anti-CNB2 (made in goat; diluted 1:15) and anti-CNA5 (made in rabbit; diluted 1:15), followed by incubation in biotinylated anti-goat IgG (diluted 1:300) and anti-rabbit IgG labeled with Texas Red (diluted 1:200). Sections were then incubated in avidin D-fluorescein (diluted 1:300) and anti-rabbit $\operatorname{IgG}$ labeled with Texas Red (diluted 1:200) for $1 \mathrm{hr}$ at $37^{\circ} \mathrm{C}$. To determine the level of nonspecific staining, some of the control sections were incubated without one or both of the primary antibodies, or replaced by normal rabbit serum. All staining reported here was abolished in the absence of primary antibody. The generation, purification, and characterization of anti-CNA5, anti-CNB2, and anti-CNE2 have been reported previously (Westenbroek et al., 1992; Yokoyama et al., 1995; Sakurai et al., 1996). The anti-synaptotagmin antibody was a generous gift of Dr. Masami Takahashi, Mitsubishi-Kasei Life Sciences Institute, Toyko, Japan (Yoshida et al., 1992).

\section{RESULTS}

\section{P/Q-type channels control release effectively}

The presynaptic $\mathrm{Ca}^{2+}$ influx and the corresponding EPSCs evoked by single action potentials were simultaneously recorded at single calyx-type synapses. Application of the $\mathrm{P} / \mathrm{Q}$-type $\mathrm{Ca}^{2+}$ channel blocker $\omega$-agatoxin-IVA (Aga, 15-200 nM) reduced both the amplitude of the presynaptic $\mathrm{Ca}^{2+}$ influx $\left(\Delta\left[\mathrm{Ca}^{2+}\right]\right)$ and the
EPSC without significantly affecting the presynaptic resting membrane potential, the shape of the action potential, or the resting intracellular $\mathrm{Ca}^{2+}$ concentration (Fig. $1 A, B$ ). This effect could not be reversed after $>30 \mathrm{~min}$ of wash out (data not shown). The relation between the EPSC and the $\Delta\left[\mathrm{Ca}^{2+}\right]$ was nonlinear (Fig. $1 C)$ and could be fit with relation (2), where $m=3.7 \pm 0.2(\mathrm{n}=$ 5 pairs of presynaptic and postsynaptic recordings, Fig. $1 D$ ). The effect of Aga was dose-dependent. It reached a plateau at $100 \mathrm{~nm}$ (Fig. $1 E)$, at which $\Delta\left[\mathrm{Ca}^{2+}\right]$ was reduced to $44 \pm 2 \%(\mathrm{n}=9)$ and the EPSC was reduced to $3 \pm 1 \%(\mathrm{n}=4)$. At $30 \mathrm{~nm}$, Aga reduced $\Delta\left[\mathrm{Ca}^{2+}\right]$ to $71 \pm 3 \%(\mathrm{n}=3$; Fig. $1 E)$ and the EPSC to $26 \pm 5 \%$ $(\mathrm{n}=6)$, yielding the value $m=3.9(\log (0.71) / \log (0.26))$. Similar values (3.3-4.2) of $m$ were obtained at concentrations of 60-200 $\mathrm{nM}$ (from data summarized in Fig. $1 E$ ). These results suggest that the value of $m$ is independent of the concentration of Aga. The $K_{\mathrm{d}}$ for the block by Aga was $\sim 30 \mathrm{nM}$, because at this concentration Aga reached about half-maximal block of the $\Delta\left[\mathrm{Ca}^{2+}\right]$ (Fig. $1 E$ ).

\section{$\mathbf{N}$-type channels control release less effectively}

Addition of the N-type channel blocker $\omega$-conotoxin-GVIA (Ctx) reduced both the $\Delta\left[\mathrm{Ca}^{2+}\right]$ and the EPSC simultaneously (Fig. $2 A$ ). The membrane potential, the action potential, and the resting intracellular $\mathrm{Ca}^{2+}$ concentration in the terminal did not change significantly (Fig. $2 B$ ). The relation between the EPSC and the $\Delta\left[\mathrm{Ca}^{2+}\right]$ could be fit with relation (2) with $m=1.3 \pm 0.1$ 

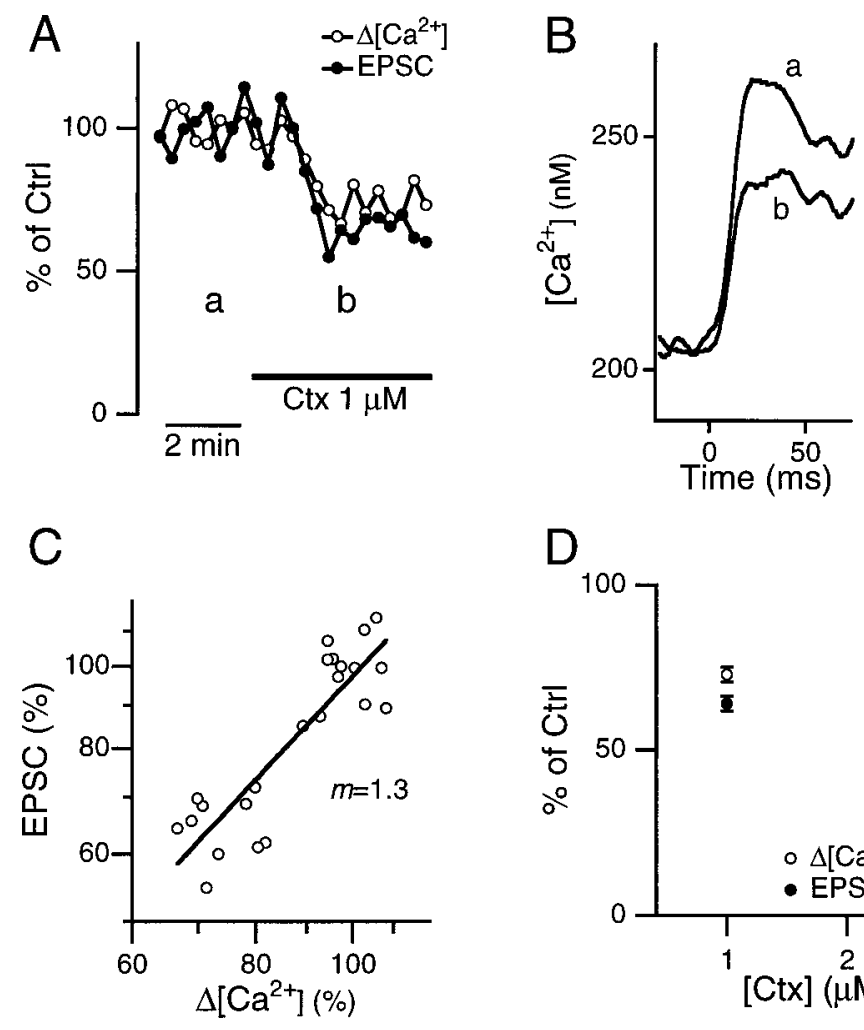

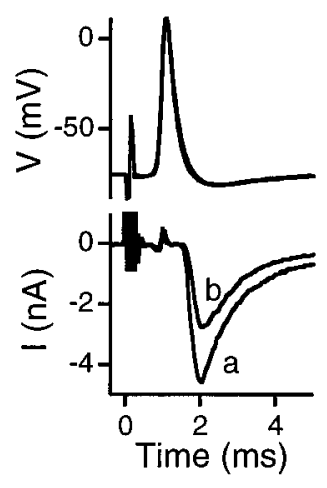

Figure 2. Effect of $\mathrm{Ctx}$ on presynaptic $\Delta\left[\mathrm{Ca}^{2+}\right]$ and EPSC. $A$, Ctx $(1 \mu \mathrm{M})$ reduced both the $\Delta\left[\mathrm{Ca}^{2+}\right]$ and the EPSC evoked by single presynaptic action potentials with a similar time course. Amplitudes of both the $\Delta\left[\mathrm{Ca}^{2+}\right]$ and the EPSC were normalized to the values during the control period. $B$, Sample traces of the presynaptic $\mathrm{Ca}^{2+}$ influx (left), the presynaptic action potential (top right), and the EPSC (bottom right) before $(a)$ and after $(b$, as indicated in $A)$ Ctx application. The stimulus was given at time $0 . C$, EPSCs plotted against the $\Delta\left[\mathrm{Ca}^{2+}\right]$ from $A$ on double logarithmic scales. The slope of the linear regression line was 1.3. $D$, Summary of the effect of Ctx on the $\Delta\left[\mathrm{Ca}^{2+}\right]$ and the EPSC. Each value was obtained from 3-11 cells. The effects of Ctx at 1 and $3 \mu \mathrm{M}$ were not significantly different ( $p>0.5 ; t$ test). (seven pairs of presynaptic and postsynaptic recordings, Fig. $2 C$ ). The value of $m$ obtained with application of Ctx was significantly lower than that with application of Aga $(p<0.01 ; t$ test $)$. At $1 \mu \mathrm{M}$, Ctx reduced the $\Delta\left[\mathrm{Ca}^{2+}\right]$ to $73 \pm 2 \%(\mathrm{n}=11)$ and the EPSC to $64 \pm 2 \%(\mathrm{n}=10$, Fig. $2 D)$. The effect of $\mathrm{Ctx}$ was saturated at 1 $\mu \mathrm{M}$, since no additional block on either the $\Delta\left[\mathrm{Ca}^{2+}\right](\mathrm{n}=3)$ or the EPSC $(\mathrm{n}=3)$ was observed at $3 \mu \mathrm{M}$ (Fig. $2 D)$.

We previously observed that combined application of saturating concentrations of $\omega$-conotoxin-MVIIC $(8 \mu \mathrm{M})$, a blocker of P/Q- and N-type channels (Hillyard et al., 1992; McDonough et al., 1996), Aga (100 nM), and Ctx $(1 \mu \mathrm{M})$ reduces the $\Delta\left[\mathrm{Ca}^{2+}\right]$ to $26 \pm 2 \%(\mathrm{n}=8)$ and the EPSC to $0.9 \pm 0.2 \%(\mathrm{n}=4$; Wu et al., 1998). Similar results were obtained when Aga and Ctx were applied together in the absence of $\omega$-conotoxin-MVIIC (Wu et al., 1998, see also Fig. 4). The block of $\Delta\left[\mathrm{Ca}^{2+}\right]$ by the combined toxin application was similar to the sum of the block by applying either Aga or Ctx alone, suggesting that Aga and Ctx block separate populations of $\mathrm{Ca}^{2+}$ channels. The resistant $\Delta\left[\mathrm{Ca}^{2+}\right]$ is mediated via R-type channels, which have $m=1.4 \pm 0.1(\mathrm{n}=4$ synapses; Wu et al., 1998). Reducing the extracellular $\mathrm{Ca}^{2+}$ concentration from 2 to $1 \mathrm{mM}$ results in $n=2.7 \pm 0.2(\mathrm{n}=5$ synapses; Wu et al., 1998). Table 1 shows the average percentages of the $\Delta\left[\mathrm{Ca}^{2+}\right]$ evoked by single action potentials from three subtypes of $\mathrm{Ca}^{2+}$ channels and their values of $m$. The sum of the three components was slightly $>100 \%$, probably because of measurement error.

\section{The difference in $\boldsymbol{m}$ is not caused by different $\mathrm{Ca}^{2+}$ current kinetics}

In the squid giant synapse, broadening presynaptic action potentials increases EPSCs (Augustine et al., 1991). The relation between the EPSC and the presynaptic $\mathrm{Ca}^{2+}$ influx was estimated to be approximately linear from this study, suggesting that during an action potential $\mathrm{Ca}^{2+}$ channel domains do not overlap at this synapse (Augustine et al., 1991). If one subtype of $\mathrm{Ca}^{2+}$ channels opens much more briefly than others, its $\mathrm{Ca}^{2+}$ domains are less likely to overlap. We wondered whether the difference in the values of $m$ at the MNTB synapse could be caused by a difference in the time course of $\mathrm{Ca}^{2+}$ currents. Presynaptic $\mathrm{Ca}^{2+}$ currents elicited by an action potential waveform command $\left(I_{\mathrm{Ca}(\mathrm{AP})}\right)$ were recorded in the presence of $\mathrm{Na}^{+}$and $\mathrm{K}^{+}$channel blockers (Borst and Sakmann, 1996). Application of $\mathrm{Ctx}(1 \mu \mathrm{M})$ reduced the amplitude of the $I_{\mathrm{Ca}(\mathrm{AP})}$ to $79 \pm 1 \%(\mathrm{n}=6$; Fig. $3 \mathrm{~A})$, similar to its inhibitory effect on the $\Delta\left[\mathrm{Ca}^{2+}\right]$ (Fig. 2). This effect was not accompanied by a significant change in the waveform of the current measured at half width $(p>0.5$; paired $t$ test; $\mathrm{n}=5$; Fig.

\begin{tabular}{|c|c|c|c|c|}
\hline & P/Q-type & N-type & R-type & Cooperativity $(n)$ \\
\hline$\%$ & $56 \pm(9)$ & $27 \pm 2(11)$ & $26 \pm 2(8)$ & \\
\hline$m$ or $n$ & $3.7 \pm 0.2(5)$ & $1.3 \pm 0.1(7)$ & $1.4 \pm 0.1(4)$ & $2.7 \pm 0.2(5)$ \\
\hline
\end{tabular}

The percentage refers to the presynaptic $\Delta\left[\mathrm{Ca}^{2+}\right]$ evoked by single action potentials. Data are expressed as mean \pm SEM (number of synapses measured). The $m$ for different subtypes of $\mathrm{Ca}^{2+}$ channels was measured based on relation (2). The $n$ for the cooperativity of the $\mathrm{Ca}^{2+}$ in triggering release was measured by lowering the extracellular $\mathrm{Ca}^{2+}$ concentration (Wu et al., 1998). 

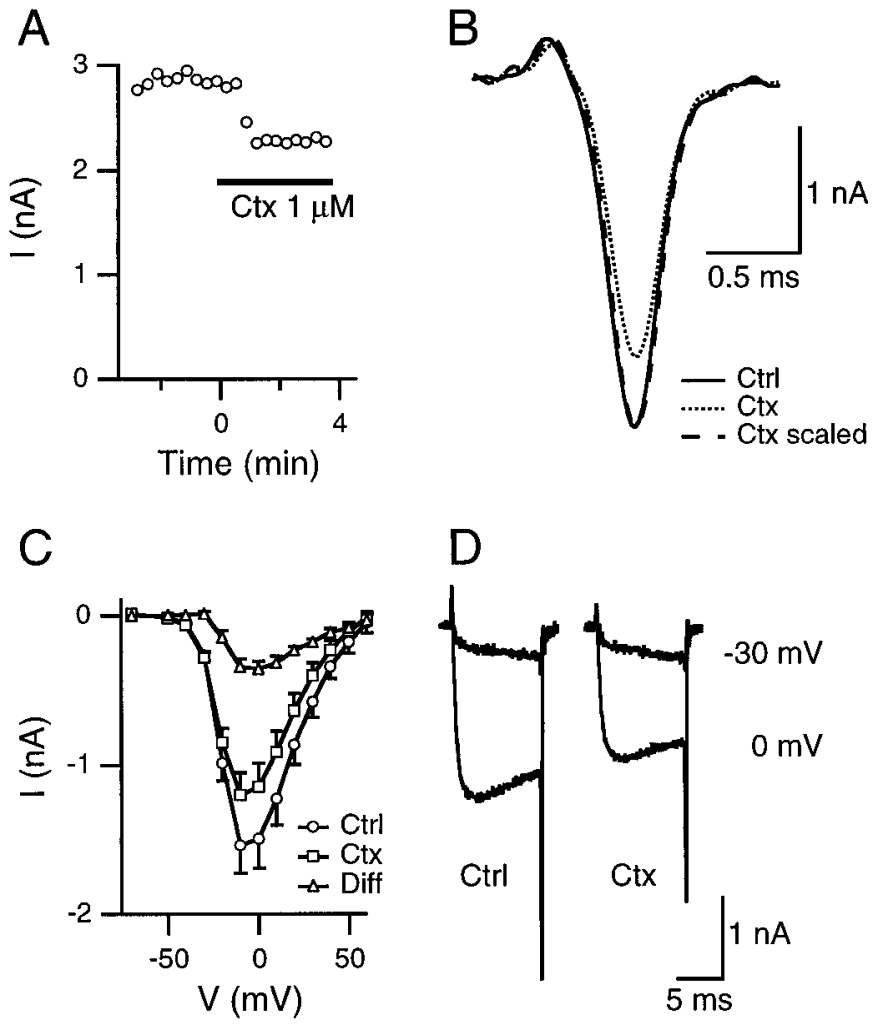

Figure 3. Presynaptic $\mathrm{Ca}^{2+}$ currents elicited by an action potential waveform command $\left(I_{\mathrm{Ca}(\mathrm{AP})}\right)$ before and after $\mathrm{Ctx}$ application. $A$, Application of Ctx $(1 \mu \mathrm{M})$ reduced the $I_{\mathrm{Ca}(\mathrm{AP})} . B$, Sample traces of the $I_{\mathrm{Ca}(\mathrm{AP})}$ before $(\mathrm{Ctrl})$ and after $\mathrm{Ctx}$ application, the latter of which was also scaled (Ctx scaled) for comparison with the $C$ trl trace. $C$, The $I-V$ relation before $(\mathrm{Ctrl})$ and after $\mathrm{Ctx}$ application. The difference between these two $I-V$ curves yielded the Ctx-sensitive $I-V$ curve (Diff), which activated at potentials more positive than $-30 \mathrm{mV}$. In contrast, the threshold for activation of $\mathrm{Ctx}$-insensitive currents $(\mathrm{Ctx})$ was at approximately -40 mV. D, Sample $\mathrm{Ca}^{2+}$ currents elicited by a $10 \mathrm{msec}$ step pulse to -30 and $0 \mathrm{mV}$ before (left) and after (right) Ctx application. Note that currents elicited at $-30 \mathrm{mV}$ did not change significantly after Ctx application.

$3 B$ ). Similarly, application of $\omega$-conotoxin-MVIIC, a blocker for $\mathrm{N}$ - and $\mathrm{P} / \mathrm{Q}$-type $\mathrm{Ca}^{2+}$ channels, revealed no significant difference in the time course of the $I_{\mathrm{Ca}(\mathrm{AP})}$ between the R-type and the total current ( $\mathrm{Wu}$ et al., 1998). These results suggest that the lower value of $m$ for $\mathrm{N}$ - and R-type channels is not caused by a difference in the kinetics of the $I_{\mathrm{Ca}(\mathrm{AP})}$.

In addition to studying the time course of the $I_{\mathrm{Ca}(\mathrm{AP})}$, we also examined the currents elicited by $10 \mathrm{msec}$ depolarizing steps from a holding potential of $-80 \mathrm{mV}$. The peak current-voltage $(I-V)$ curves were obtained before and after $\mathrm{Ctx}$ application $(\mathrm{n}=6$; Fig. $3 C, D)$. The difference between these two $I-V$ curves is the Ctxsensitive N-type current, which activated at potentials more positive than $-30 \mathrm{mV}$ (Fig. $3 C, D$ ), at least $10 \mathrm{mV}$ more positive than the other two subtypes of $\mathrm{Ca}^{2+}$ currents. $\mathrm{Ctx}(1 \mu \mathrm{M})$ inhibited the current elicited at $0 \mathrm{mV}$ to $76 \pm 3 \%(\mathrm{n}=6)$ of control. A similar block was observed at -10 to $30 \mathrm{mV}$. These results were similar to the effect of $\mathrm{Ctx}$ on $\Delta\left[\mathrm{Ca}^{2+}\right]$ or $I_{\mathrm{Ca}(\mathrm{AP})}$ (Figs. 2, 3).

\section{Multiple subtypes of $\mathrm{Ca}^{2+}$ channels control release at single release sites}

Next, we investigated whether the difference in the value of $m$ could be accounted for by differential distribution of $\mathrm{Ca}^{2+}$ chan- nel subtypes at different release sites. Because Aga blocked $97 \pm$ $1 \%$ of the EPSC (Fig. $1 E$ ), we assumed that P/Q-type channels participate in controlling release at all release sites. In a calyx, about half of the $\mathrm{Ca}^{2+}$ influx is via $\mathrm{P} / \mathrm{Q}$-type channels, and the other half is approximately equally divided between $\mathrm{N}$ - and R-type channels (Table 1). We investigated three hypotheses that may account for the lower values of $m$ for $\mathrm{N}$ - and R-type channels (see introductory remarks). First, N- and R-type channels may be associated with different release sites. Second, N- and R-type channels may be located at every release site, but they may be further from the $\mathrm{Ca}^{2+}$ sensor than P/Q-type channels. Third, there may be distant $\mathrm{Ca}^{2+}$ channels, which are located so far away from release sites that they do not contribute to release during a single action potential. The fraction of distant $\mathrm{N}$ - and R-type channels may be larger than that of distant P/Q-type channels.

If $\mathrm{N}$ - and R-type channels do not control release at the same release site, the $\mathrm{Ca}^{2+}$ influx at each release site should be contributed about half by P/Q-type channels and half by either $\mathrm{N}$ - or R-type channels. This arrangement of $\mathrm{Ca}^{2+}$ channels would result in a lower value of $m$ for $\mathrm{N}$ - and R-type channels (Reid et al., 1998; see also Appendix for details). It predicts that when $\mathrm{P} / \mathrm{Q}$-type channels are completely blocked, blocking N-type channels will reduce release by $\leq 50 \%$, because only half of release sites are associated with N-type channels. In the presence of Aga (100 nM) to completely block P/Q-type channels, application of $\mathrm{Ctx}(1 \mu \mathrm{M})$ reduced the $\Delta\left[\mathrm{Ca}^{2+}\right]$ by $52 \pm 2 \%(\mathrm{n}=5)$ of the value immediately before $\mathrm{Ctx}$ application (Fig. 4), as expected from Table 1 . However, Ctx reduced the EPSC by $78 \pm 4 \%(n=4)$ of the value immediately before $\mathrm{Ctx}$ application, which is clearly higher than the predicted $50 \%$. Thus, the hypothesis that $\mathrm{N}$ - and R-type channels are associated with different release sites is not supported. N-type channels are present in at least $78 \%$ of release sites. These results suggest that transmitter release at most release sites is controlled by three subtypes of $\mathrm{Ca}^{2+}$ channels, $\mathrm{P} / \mathrm{Q}-, \mathrm{N}-$, and R-type. As an approximation, we assumed that all three subtypes of channels control release at every release site.

\section{EGTA does not preferentially block release mediated by $\mathrm{N}$-type $\mathrm{Ca}^{2+}$ channels}

If $\mathrm{N}$ - and R-type channels near release sites were located further from the $\mathrm{Ca}^{2+}$ sensor than $\mathrm{P} / \mathrm{Q}$-type channels, the $\mathrm{Ca}^{2+}$ entering via $\mathrm{N}$ - or R-type channels is less likely to bind to the $\mathrm{Ca}^{2+}$ sensor than that entering the terminal via $\mathrm{P} / \mathrm{Q}$-type channels. This will result in a lower value of $m$ for $\mathrm{N}$ - and R-type channels. One prediction of this hypothesis is that the $\mathrm{Ca}^{2+}$ entering via $\mathrm{N}$ - or $\mathrm{R}$-type channels will diffuse across a longer distance to reach the $\mathrm{Ca}^{2+}$ sensor, and thus will be more likely to be bound by an exogenous $\mathrm{Ca}^{2+}$ buffer. We tested whether release controlled by the $\mathrm{Ca}^{2+}$ influx through $\mathrm{N}$-type channels is more susceptible to the block by a high concentration of the slow $\mathrm{Ca}^{2+}$ buffer EGTA. EPSCs were recorded while a pipette containing $10 \mathrm{~mm}$ EGTA was sealed to the corresponding terminal in the cell-attached configuration. After obtaining a baseline value for the EPSC amplitude, the whole-cell configuration was established in the presynaptic recording. The EPSC decreased to a new steady-state level in $\sim 3$ min (Fig. $5 A$ ), probably reflecting diffusion of EGTA from the presynaptic pipette into the terminal (Borst and Sakmann, 1996). Application of $\mathrm{Ctx}(1 \mu \mathrm{M})$ further reduced the EPSC by $38 \pm 5 \%(\mathrm{n}=5)$ of the value at the new steady-state level (Fig. $5 A$ ). Ctx blocked a similar fraction of the EPSC in the presence or absence of EGTA (Fig. $5 B$ ). These results suggest 
A

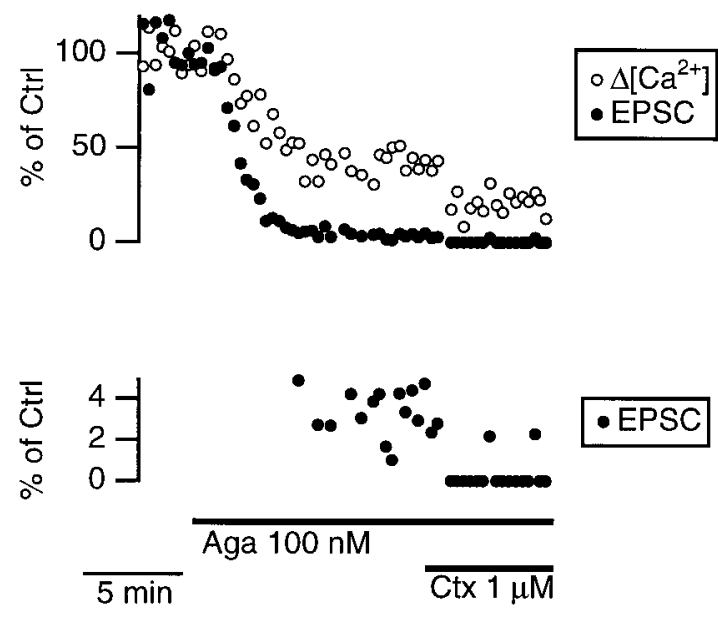

B

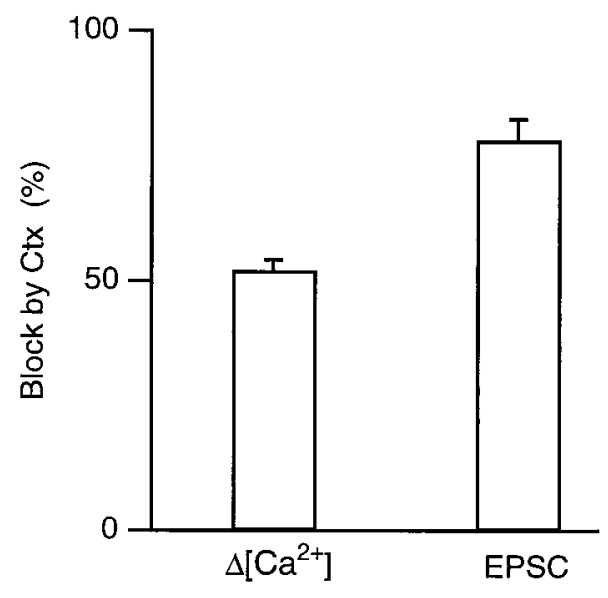

Figure 4. Effect of Ctx on $\Delta\left[\mathrm{Ca}^{2+}\right]$ and EPSC in the presence of Aga. $A$, An experiment showing that Ctx $(1 \mu \mathrm{M})$ reduced both the $\Delta\left[\mathrm{Ca}{ }^{2+}\right]$ and the EPSC in the presence of Aga $(100 \mathrm{nM})$. In the bottom panel, the EPSC is plotted on a different scale. If the maximum amplitude of the postsynaptic current was less than twice the SD of the baseline noise, the response was classified as a failure. $B$, In the presence of Aga (100 nM), the block (\%) of the $\Delta\left[\mathrm{Ca}^{2+}\right]$ and of the EPSC by Ctx $(1 \mu \mathrm{M})$ were significantly different $(p<0.01$; paired $t$ test). The percentages were normalized to the values immediately before Ctx application.

that calcium ions that reach the $\mathrm{Ca}^{2+}$ sensor diffuse approximately the same distance, irrespective of the subtype of channels through which they enter.

\section{Double labeling with antibodies to $\mathrm{Ca}^{2+}$ channels and synaptotagmin}

If a larger fraction of $\mathrm{N}$ - and R-type channels than $\mathrm{P} / \mathrm{Q}$-type channels were located far from release sites, from which $\mathrm{Ca}^{2+}$ entering will be less likely to bind to the $\mathrm{Ca}^{2+}$ sensor that triggers release, the value of $m$ for $\mathrm{N}$ - or R-type will be lower than that for $\mathrm{P} / \mathrm{Q}$-type channels. To address this hypothesis, we examined the distribution of $\mathrm{Ca}^{2+}$ channels in the terminal by double labeling with antibodies to $\mathrm{Ca}^{2+}$ channels (Westenbroek et al., 1992, 1995; Yokoyama et al., 1995) and to synaptotagmin, a synaptic vesicle protein (Brose et al., 1992). Confocal microscopic examination of tissue sections labeled with monoclonal antibodies against synaptotagmin (Yoshida et al., 1992) revealed staining that was restricted to the presynaptic calyx terminal enveloping the cell body of MNTB neurons (Fig. 6B). In contrast, immunostaining for the $\alpha_{1 \mathrm{~A}}$ subunit of $\mathrm{P} / \mathrm{Q}$-type $\mathrm{Ca}^{2+}$ channels (Westenbroek et al., 1995) was localized in punctate clusters in the release face of the calyx-type synapse along the surface of the cell, as well as scattered throughout the postsynaptic cell body (Fig. 6A). Staining in the soma presumably represents newly synthesized P/Q-type channels in the endoplasmic reticulum and Golgi complex, which were more prominent in these neurons in young rats than we previously observed in adults (Westenbroek et al., 1995). Merged images showed that staining for $\alpha_{1 \mathrm{~A}}$ was colocalized with staining for synaptotagmin at sites along the release face of the calyx (Fig. $6 C$, yellow-orange regions). Although some punctate staining of $\alpha_{1 \mathrm{~A}}$ appeared to be in the cytosol of the terminal in a single optical section (about $1 \mu \mathrm{m}$ ), inspection of adjacent sections suggested that it originated from the irregularly shaped release face as well. This staining was carried out using anti-CNA5 antibodies, which recognize the rbA isoform of $\alpha_{1 \mathrm{~A}}$ (Starr et al., 1991; Sakurai et al., 1996). A similar pattern of staining was observed with the anti-CNA6 antibodies against the BI isoform (Mori et al., 1991; Sakurai et al., 1996). Altogether, these results show that many areas of the calyx synapse that were labeled for synaptotagmin were also labeled for both isoforms of the $\alpha_{1 \mathrm{~A}}$ subunits of $\mathrm{P} / \mathrm{Q}$-type $\mathrm{Ca}^{2+}$ channels.

Examination of tissue sections labeled with antibodies to $\alpha_{1 \mathrm{~B}}$ subunit of $\mathrm{N}$-type $\mathrm{Ca}^{2+}$ channels revealed staining of this channel along both the release face and the nonrelease face of the calyx, as well as substantial intracellular staining in the cell body of
Figure 5. Effect of Ctx on EPSC after EGTA was dialyzed into the terminal. $A$, While the EPSC was recorded, a cell-attached recording was made on the presynaptic terminal with a pipette containing $10 \mathrm{~mm}$ EGTA. A suction pulse (arrow) was applied to establish the whole-cell configuration, allowing EGTA to diffuse from the pipette into the terminal. The EPSC decreased rapidly and reached a new baseline value. Ctx $(1 \mu \mathrm{M})$ was then applied to the bath, which further decreased the EPSC. $B$, Comparison of the block of the EPSC by Ctx $(1 \mu \mathrm{M})$ in the control $(\mathrm{Ctrl} ; \mathrm{n}=10)$ and after EGTA $(\mathrm{n}=5)$ was dialyzed into the presynaptic terminal. In both cases, the block was normalized to the value immediately before Ctx application.
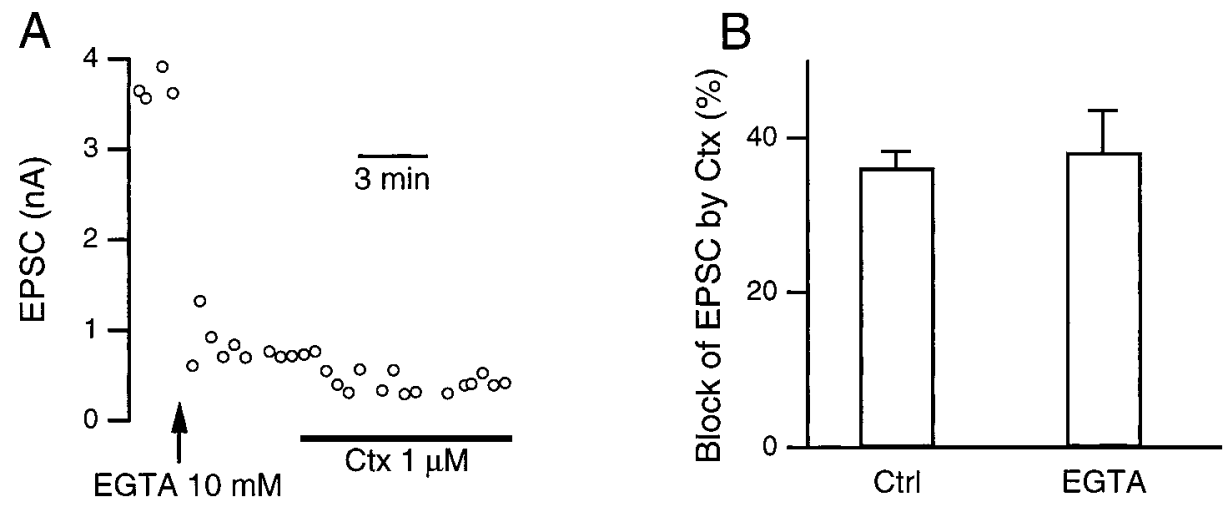

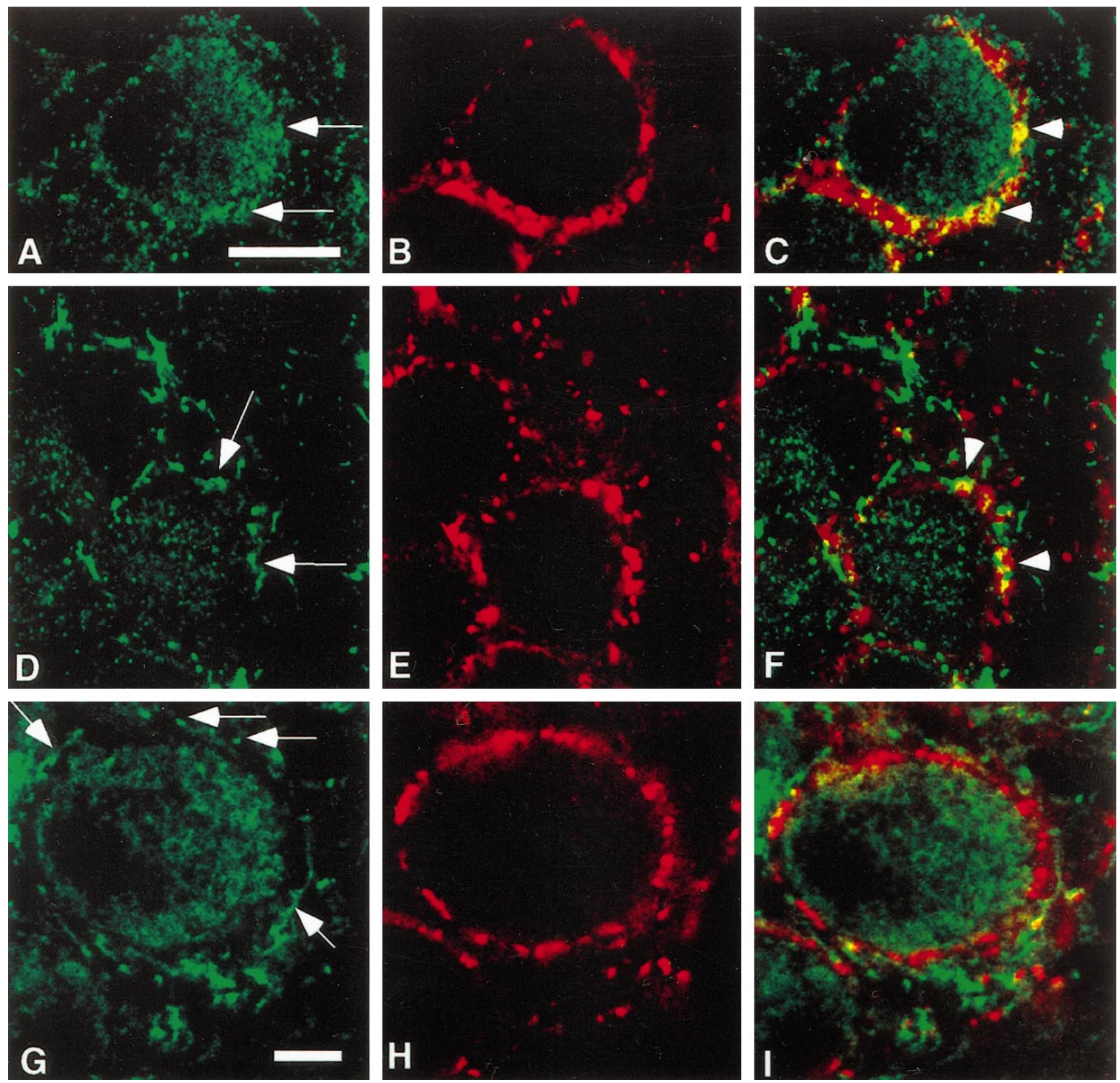

Figure 6. Distribution of the $\alpha_{1}$ subunit of classes A, B, and $\mathrm{E} \mathrm{Ca}^{2+}$ channels in synapses in the MNTB. $A, B$, Tissue section double-labeled using antibodies to the $\alpha_{1}$ subunit of class $\mathrm{A} \mathrm{Ca}^{2+}$ channels $(A$, arrows $)$ and anti-synaptotagmin $(B)$, illustrating their distribution in the synapse surrounding neurons located in the MNTB. $C$, Merged image of $A$ and $B$ illustrating regions of colocalization (yellow; arrowheads) between the $\alpha_{1}$ subunit of class $\mathrm{A} \mathrm{Ca}^{2+}$ channels ( green) and synaptotagmin (red), demonstrating the presence of these channels at the release face of the synapse. $D, E$, Tissue section double-labeled using antibodies to the $\alpha_{1}$ subunit of class $\mathrm{B} \mathrm{Ca}^{2+}$ channels $(D$, arrows $)$ and anti-synaptotagmin $(E)$, illustrating their distribution in the synapse surrounding MNTB neurons. $F$, Merged image of the staining observed in $D$ and $E$, illustrating few regions of colocalization (yellow, arrowheads) between class $\mathrm{B} \mathrm{Ca}^{2+}$ channels and synaptotagmin in the synapse and the presence of class $\mathrm{B} \mathrm{Ca}^{2+}$ channels in other regions of the synapse. $G, H$, Tissue section double-labeled with antibodies to the $\alpha_{1}$ subunit of class $\mathrm{E} \mathrm{Ca}^{2+}$ channels $(G$, arrows) and anti-synaptotagmin antibodies $(H)$, illustrating the presence of synaptotagmin at the release face of the synapse and the distribution of class E channels at other sites in the synapse. $I$, Merged image of the staining shown in $G$ and $H$, illustrating very few sites of colocalization ( yellow) of these two proteins. Arrows illustrate sites of class E Ca ${ }^{2+}$ channels outside the release face of the synapse. Scale bars: $A-F, 10 \mu \mathrm{m} ; G-I, 5 \mu \mathrm{m}$.

postsynaptic neurons (Fig. $6 D$ ). N-type $\mathrm{Ca}^{2+}$ channel staining of the calyx was often adjacent to or surrounding the staining observed with anti-synaptotagmin antibodies rather than superimposed on it (Fig. 6, compare $D, E$ ). Merged images showed areas of superimposition of staining for synaptotagmin and $\mathrm{N}$-type $\mathrm{Ca}^{2+}$ channels (Fig. $6 F$, yellow-orange staining), but many areas of synaptotagmin staining did not have colocalized N-type $\mathrm{Ca}^{2+}$ channels (Fig. $6 F$, red staining), and many areas of staining for N-type $\mathrm{Ca}^{2+}$ channels were not stained for synaptotagmin (Fig. $6 F$, bright green staining). Immunostaining for $\mathrm{N}$-type $\mathrm{Ca}^{2+}$ channels was also present along the outer surface of the calyx and appeared to extend along the surface membrane of calyx to areas adjacent to the axon, where no synaptotagmin staining was observed (data not shown).

Antibodies against the $\alpha_{1 \mathrm{E}}$ subunits of R-type $\mathrm{Ca}^{2+}$ channels were mostly not colocalized with synaptotagmin antibodies (Fig. 6, compare $G, H)$. Merged images show few areas of superimposition of staining for $\alpha_{1 \mathrm{E}}$ and synaptotagmin (Fig. 6I). These R-type channels appeared present primarily along the outer surface of the calyx and only rarely on the inner surface that surrounds the neurons and contains the sites of neurotransmitter release. Staining for $\alpha_{1 \mathrm{E}}$ also extended to areas adjacent to the axon where no staining for synaptotagmin was observed.

Double-labeling studies using antibodies to N-type and P/Q- 

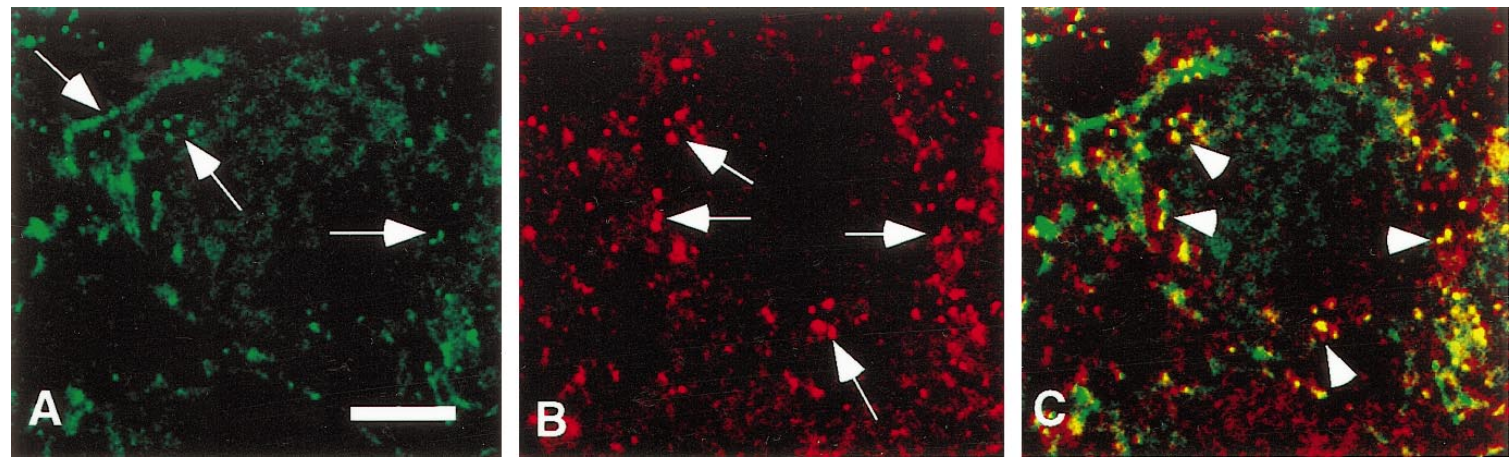

Figure 7. Double labeling of class A and class $\mathrm{B} \mathrm{Ca}{ }^{2+}$ channels in the MNTB. $A, B$, Double labeling of a tissue section from the MNTB using antibodies to the class B $(A$, arrows $)$ and class $\mathrm{A}\left(B\right.$, arrows) $\alpha_{1}$ subunits of $\mathrm{Ca}^{2+}$ channels. $C$, Merged image of staining shown in $A$ and $B$ to illustrate regions of only class B staining (green), or regions of only class A staining (red) and regions of colocalization (yellow, arrowheads) of these two channels in the synapses and neurons located in the MNTB. Scale bar: $A-C, 10 \mu \mathrm{m}$.

type $\mathrm{Ca}^{2+}$ channels revealed distinct distributions of these channels. $\mathrm{P} / \mathrm{Q}$-type $\mathrm{Ca}^{2+}$ channels are located in punctate clusters in the calyx membrane (Fig. $7 B$ ), whereas $\mathrm{N}$-type channels are more diffusely distributed throughout the calyx (Fig. 7A). Merging these images shows that $\mathrm{N}$-type $\mathrm{Ca}^{2+}$ channels often are colocalized with $\mathrm{P} / \mathrm{Q}$-type channels (Fig. 7C, yellow-orange staining) but also are often located elsewhere in the calyx (Fig. $7 C$, green staining). The double-labeled images are consistent with the conclusion that $\mathrm{N}$-type $\mathrm{Ca}^{2+}$ channels are colocalized with $\mathrm{P} / \mathrm{Q}$-type $\mathrm{Ca}^{2+}$ channels in release sites, but are also localized elsewhere in the calyx terminals.

\section{DISCUSSION}

We have demonstrated that three classes of $\mathrm{Ca}^{2+}$ channels, R(Wu et al., 1998), P/Q-, and N-type control transmitter release at single release sites in single calyx-type terminals in the rat MNTB. The value of $m$ for P/Q-type channels was higher than for $\mathrm{N}$ - and R-type channels, meaning that $\mathrm{P} / \mathrm{Q}$-type channels trigger release more effectively than $\mathrm{N}$ - and $\mathrm{R}$-type. This difference was not caused by a difference in their kinetic properties or by a greater diffusional distance between the N-type or R-type $\mathrm{Ca}^{2+}$ channels that contributed to transmitter release and the

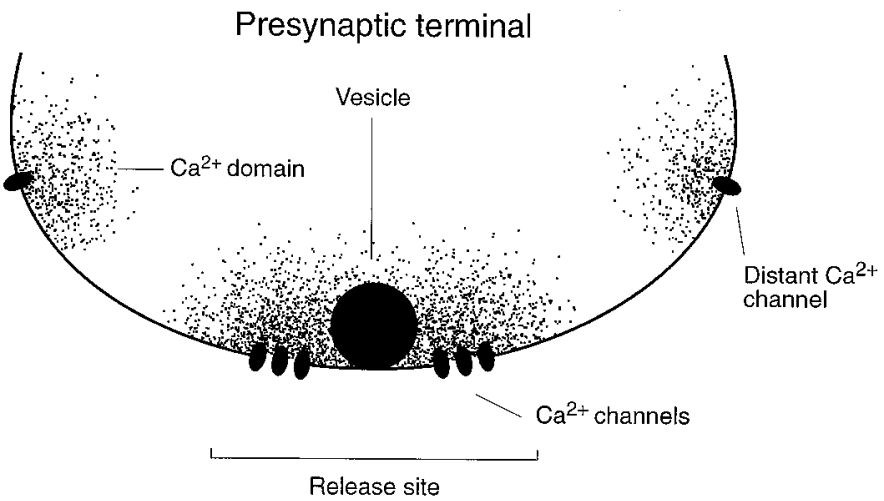

Figure 8. A schematic view of the distribution of $\mathrm{Ca}^{2+}$ channels in the calyx of Held (not drawn to scale). Within a release site, three subtypes of channels, P/Q-, N-, and R-type channels are equally close to the docked vesicle. The local $\mathrm{Ca}^{2+}$ domains created by the opening of channels overlap within the release site. Some $\mathrm{Ca}^{2+}$ channels, labeled as "distant $\mathrm{Ca}^{2+}$ channel", are located so far from this or other release sites that their $\mathrm{Ca}^{2+}$ domains do not contribute to release. A larger fraction of $\mathrm{N}-$ and $\mathrm{R}$-type than $\mathrm{P} / \mathrm{Q}$-type channels are distant $\mathrm{Ca}^{2+}$ channels.
$\mathrm{Ca}^{2+}$ sensor that triggered release. Double immunocytochemical labeling showed that $\mathrm{P} / \mathrm{Q}$-type $\mathrm{Ca}^{2+}$ channels containing $\alpha_{1 \mathrm{~A}}$ subunits were colocalized mostly with synaptic vesicle clusters, whereas N-type channels containing $\alpha_{1 \mathrm{~B}}$ and R-type channels containing $\alpha_{1 \mathrm{E}}$ were only partly colocalized with vesicle clusters. These results suggest that the subcellular distribution of $\mathrm{Ca}^{2+}$ channels within a terminal is one of the factors that determines their effectiveness in triggering release. As summarized in Figure 8 , our results are best explained by assuming that a larger fraction of N-and R-type channels are localized distant from release sites. However, within a release site, all three subtypes of channels are localized at a similar distance from the $\mathrm{Ca}^{2+}$ sensor.

\section{Multiple subtypes of $\mathrm{Ca}^{2+}$ channels in the calyx of Held}

Takahashi et al. (1996) reported that the majority (96\%) of the presynaptic $\mathrm{Ca}^{2+}$ current at the rat MNTB synapse is Agasensitive $\mathrm{P} / \mathrm{Q}$-type and that $\mathrm{C}$ tx has no effect on the presynaptic $\mathrm{Ca}^{2+}$ current. This is not consistent with our results (Table 1). The rats used by Takahashi et al. (1996) were 8- to 18-d-old, whereas we used 8- to 10-d-old rats. A developmental change of presynaptic $\mathrm{Ca}^{2+}$ channel subtypes in the MNTB (Iwasaki and Takahashi, 1998) might partly account for this discrepancy, although in contrast to our results, Iwasaki and Takahashi (1998) did not observe a contribution of $\mathrm{N}$-type $\mathrm{Ca}^{2+}$ channels to synaptic transmission in 10-d-old rats. Several lines of evidence support that three subtypes rather than a single subtype of $\mathrm{Ca}^{2+}$ channels are present in 8- to 10-d-old rats. Aga blocked slightly more than half of the total presynaptic $\mathrm{Ca}^{2+}$ current at $100 \mathrm{~nm}$. $\mathrm{C}$ tx blocked about a quarter of the presynaptic $\mathrm{Ca}^{2+}$ current and $\sim 35 \%$ of the EPSC at saturating concentrations. Ctx from two sources (Bachem and Research Biochemicals) was used, and no significant difference was noticed. The threshold for activation of the Ctx-sensitive current was at least $10 \mathrm{mV}$ more positive than that of the $\mathrm{Ctx}$-insensitive current, indicating that the biophysical properties of the $\mathrm{N}$-type current are different from the $\mathrm{Ctx}$ insensitive current. In addition, the $\mathrm{N}$ - and P/Q-type channel blocker $\omega$-conotoxin-MVIIC reaches its maximal effect at $8 \mu \mathrm{M}$ by blocking about three quarters of the $\mathrm{Ca}^{2+}$ current $(\mathrm{Wu}$ et al., 1998), similar to the summed effect of coapplication of Aga and Ctx (Table 1). Coapplication of $\omega$-conotoxin-MVIIC, Aga, and $\mathrm{Ctx}$ at saturating concentrations causes a similar effect as applying only $\omega$-conotoxin-MVIIC (Wu et al., 1998). The $\omega$-conotoxinMVIIC-sensitive current showed a slowly activating component 
when activated at -30 to $-20 \mathrm{mV}$, whereas $\omega$-conotoxin-MVIICinsensitive R-type current does not have this component ( $\mathrm{Wu}$ et al., 1998). This result suggests that the R-type current is kinetically different from other subtypes of currents. Furthermore, immunostaining showed that $\alpha_{1 \mathrm{~A}}$ subunits of P/Q-type, $\alpha_{1 \mathrm{~B}}$ subunits of N-type, and $\alpha_{1 \mathrm{E}}$ subunits of R-type $\mathrm{Ca}^{2+}$ channels are mostly or partly localized at the presynaptic release sites. Taken together, the pharmacological evidence shows the presence of three subtypes of $\mathrm{Ca}^{2+}$ channels in a single terminal, which differ in their threshold of activation, current kinetics, and the composition of their $\alpha_{1}$ subunits.

In neuronal somata, the percentages of different $\mathrm{Ca}^{2+}$ currents evoked by a depolarizing voltage step may be different from that evoked by an action potential (McCobb and Beam, 1991; Scroggs and Fox, 1992). Whether this is also the case in synaptic terminals had previously not been examined. Ctx and $\omega$-conotoxin-M VIIC (Wu et al., 1998) reduced the $\mathrm{Ca}^{2+}$ influx by an action potential to a similar degree as the current evoked by a depolarizing voltage step. These results suggest that none of the three subtypes of $\mathrm{Ca}^{2+}$ channels is preferentially activated by action potentials.

\section{Different effectiveness of $\mathbf{C a}^{2+}$ channel subtypes}

If release rates are close to maximal, the relation between $\mathrm{Ca}^{2+}$ influx and release becomes less steep. Blocking a small fraction of $\mathrm{Ca}^{2+}$ channels would then cause a relatively small effect on release and thus cause an apparently smaller effectiveness of $\mathrm{Ca}^{2+}$ channels in controlling release (Turner et al., 1993; Wheeler et al., 1996). Could the low value of $m$ for the N-type or the R-type $\mathrm{Ca}^{2+}$ channels observed in our experiments be caused by saturation of the release process? Because Aga, at $30 \mathrm{~nm}$, gave a similar reduction in $\Delta\left[\mathrm{Ca}^{2+}\right]$, but a much larger reduction in the EPSC than $1 \mu \mathrm{M} C t x$, this possibility is unlikely. When extracellular $\mathrm{Ca}^{2+}$ concentration was reduced from 2 to $1 \mathrm{~mm}$, a large effect on the release was also observed (Wu et al., 1998), again suggesting that at physiological extracellular $\mathrm{Ca}^{2+}$ concentrations, release rates are submaximal.

The value of $m$ for P/Q- and N-type channels has also been measured for populations of other synapses $(\mathrm{Wu}$ and Saggau, 1994; Mintz et al., 1995; Qian et al., 1997). The value of $m$ is slightly lower for the N-type $(m=3.5)$ than for the P/Q-type channels ( $m=4.1-4.2)$ in guinea pig and rat hippocampal synapses (Wu and Saggau, 1994; Qian et al., 1997). This difference is more pronounced ( $m=2.5$ for the N-type and 4.0 for the P-type) at cerebellar parallel fiber synapses (Mintz et al., 1995). At MNTB synapse the largest difference is in the values of $m$ for $\mathrm{P} / \mathrm{Q}$ - and N-type channels (Table 1). Consistent with results in cerebellar and hippocampal synapses, the $m$ for the P/Q-type channels is also the highest in the MNTB synapse and it seems possible that the high $m$ value observed by Mintz et al. (1995) for the $\mathrm{P} / \mathrm{Q}$-type channels is related to the presence of toxin-resistant channels with a relatively low effectiveness in the parallel fiber terminals, similar to the situation in the MNTB.

$\mathrm{Ca}^{2+}$ domains caused by the opening of three subtypes of channels are likely to overlap at single release sites at MNTB synapses, consistent with our earlier results (Borst and Sakmann, 1996, 1998, 1999) and with results obtained in hippocampal (Wu and Saggau, 1994) and cerebellar (Mintz et al., 1995) synapses. At the MNTB synapse at least three $\mathrm{Ca}^{2+}$ channels, each of a different subtype, can contribute to release of a vesicle in the calyx. Although probably $>60 \mathrm{Ca}^{2+}$ channels open for each vesicle that is released during an action potential (Borst and
Sakmann, 1996), a significant fraction of N- and R-type $\mathrm{Ca}^{2+}$ channels may be distant channels that do not contribute to release evoked by a single action potential.

\section{Different localization of $\mathrm{Ca}^{2+}$ channel subtypes}

Double labeling with antibodies to different $\mathrm{Ca}^{2+}$ channel subtypes and to the vesicle protein synaptotagmin provided a direct comparison of localization of $\mathrm{Ca}^{2+}$ channel subtypes and release sites at a nerve terminal. The $\alpha_{1 \mathrm{~A}}$ subunits of $\mathrm{P} / \mathrm{Q}$-type $\mathrm{Ca}^{2+}$ channels are highly effective in triggering release and are colocalized in clusters with synaptotagmin, apparently at the release face of the calyx, whereas the $\alpha_{1 \mathrm{~B}}$ subunits of $\mathrm{N}$-type and $\alpha_{1 \mathrm{E}}$ subunits of R-type $\mathrm{Ca}^{2+}$ channels are partly or mostly not colocalized at release sites and P/Q-type channels. The correlation between the effectiveness in triggering release and colocalization with synaptotagmin suggests that $\mathrm{Ca}^{2+}$ channel localization can determine its effectiveness in triggering release.

Given a similar low value of $m$ for $\mathrm{N}$ - and R-type channels (Table 1), why does it appear that a larger fraction of $\alpha_{1 \mathrm{E}}$ subunits of R-type than $\alpha_{1 \mathrm{~B}}$ subunits of $\mathrm{N}$-type $\mathrm{Ca}^{2+}$ channels are not located at release sites? The $m$ value for R-type $\mathrm{Ca}^{2+}$ channels was measured using the blocker $\mathrm{Ni}^{2+}$, which reduced presynaptic $\mathrm{Ca}^{2+}$ influx primarily, but not exclusively, by blocking R-type $\mathrm{Ca}^{2+}$ currents (Wu et al., 1998). Thus, the $m$ value measured this way could have been an overestimate. Alternatively, there may be two subtypes of R-type channels (Tottene et al., 1996; Wu et al., 1998), one of which is not recognized by the antibody against the $\alpha_{1 \mathrm{E}}$ subunit and is located at the release site.

One mechanism contributing to localization of $\mathrm{Ca}^{2+}$ channels at release sites is thought to be binding of the synaptic protein interaction (synprint) site on $\mathrm{N}$ - and $\mathrm{P} / \mathrm{Q}$-type $\mathrm{Ca}^{2+}$ channels to SNARE proteins (Sheng et al., 1994; Rettig et al., 1996). Disruption of this interaction reduces the effectiveness of $\mathrm{Ca}^{2+}$ entry through $\mathrm{N}$-type channels in triggering transmitter release at cholinergic synapses between pairs of cultured sympathetic ganglion neurons and between cultured motor neurons and muscle cells (Mochida et al., 1996; Rettig et al., 1997). The different localization of $\mathrm{Ca}^{2+}$ channels observed here could reflect competition among $\mathrm{Ca}^{2+}$ channel subtypes for localization at release sites, with $\mathrm{P} / \mathrm{Q}$-type channels having a higher affinity than N-type or R-type channels for the SNARE complex in the calyx.

\section{Contribution of channel subtypes to transmitter release}

This particular arrangement of $\mathrm{Ca}^{2+}$ channel subtypes at terminals may have an important functional impact on various aspects of synaptic transmission. For example, distant $\mathrm{Ca}^{2+}$ channels located far from release sites may contribute little to the local increase in $\mathrm{Ca}^{2+}$ concentration that triggers transmitter release (Fig. 8), but may contribute to the residual $\mathrm{Ca}^{2+}$ concentration following an action potential which influences different forms of short-term synaptic plasticity such as paired-pulse facilitation and post-tetanic potentiation (Zucker, 1996). Several neurotransmitters and neuromodulators inhibit transmitter release by modulation of presynaptic $\mathrm{Ca}^{2+}$ channels (Wu and Saggau, 1997). Modulation of the highly effective $\mathrm{Ca}^{2+}$ channel subtypes will have a larger effect on transmitter release, whereas modulation of the less effective channel subtypes will cause a smaller change of transmitter release. Modulation of distant $\mathrm{Ca}^{2+}$ channels will only affect release during high-frequency signaling. 


\section{APPENDIX}

\section{Nonuniform distribution of different subtypes of $\mathrm{Ca}^{2+}$ channels at different release sites leads to a lower value of $\boldsymbol{m}$}

Lowering the extracellular $\mathrm{Ca}^{2+}$ concentration decreases the driving force for the $\mathrm{Ca}^{2+}$ influx through every $\mathrm{Ca}^{2+}$ channel, although there might be minor differences between $\mathrm{Ca}^{2+}$ channel subtypes in their affinity for extracellular $\mathrm{Ca}^{2+}$. The $n(=2.7 \pm$ $0.2 ; 5$ synapses) measured this way (Wu et al., 1998) is likely to reflect the cooperativity of $\mathrm{Ca}^{2+}$ in triggering release (Augustine et al., 1991; Mintz et al., 1995). Thus, we regarded the value of $n$ in each release site as 2.7 (Table 1). Since Aga blocked $97 \pm 1 \%$ of the EPSC, we assumed that P/Q-type channels contributed to release at all release sites. Table 1 shows the percentage of the presynaptic $\mathrm{Ca}^{2+}$ influx contributed by each subtype of channels. By scaling the measured percentages down by $8 \%$, the sum of three components (mean only) is exactly $100 \%$, which simplified the calculations below. After scaling, P/Q-type channels contributed $\sim 50 \%$ of the total $\mathrm{Ca}^{2+}$ influx, whereas $\mathrm{N}$ - and R-type each contributed $\sim 25 \%$. Thus, $50 \%$ of the $\mathrm{Ca}^{2+}$ influx at each release site is contributed by $\mathrm{P} / \mathrm{Q}$-type channels. $\mathrm{N}$ - and R-type channels share their targeted release sites with P/Q-type channels.

If $\mathrm{N}$ - and R-type channels are separated in every release site, $\mathrm{P}$ - and N-type channels control release in 50\% of release sites, whereas P- and R-type channels control release in the other $50 \%$ of release sites. When N-type channels $(\sim 25 \%$ of total channels, Table 1) are blocked, at $50 \%$ of release sites $\mathrm{Ca}^{2+}$ will enter exclusively via P/Q-type channels, and the remaining 50\% of release sites will be unaffected. The remaining fraction of release (Release normalized $_{\text {) }}$ after the block of N-type channels is: Release $_{\text {normalized }}=50 \% *\left(0.5^{2.7}\right)+50 \% *\left(1^{2.7}\right)=58 \%$. The apparent power can be measured from relation (2), 58\% $=(1-$ $0.25)^{\mathrm{m}}, m=1.9$, close to the measured value $(m=1.3 \pm 0.1)$. Similar calculations were made for R-type channels, yielding similar results. This view could account at least partly for the lower values of $m$ (see also Reid et al., 1998).

\section{REFERENCES}

Artalejo CR, Adams ME, Fox AP (1994) Three types of $\mathrm{Ca}^{2+}$ channel trigger secretion with different efficacies in chromaffin cells. Nature 367:72-76.

Augustine GJ, Adler, EM, Charlton MP (1991) The calcium signal for transmitter secretion from presynaptic nerve terminals. Ann NY Acad Sci 635:365-381.

Borst JGG, Sakmann B (1996) Calcium influx and transmitter release in a fast CNS synapse. Nature 383:431-434.

Borst JGG, Sakmann B (1998) Calcium current during a single action potential in a large presynaptic terminal of the rat brainstem. J Physiol (Lond) 506:143-157.

Borst JGG, Sakmann B (1999) Effect of changes in action potential shape on calcium currents and transmitter release in a calyx-type synapse of the rat auditory brainstem. Philos Trans R Soc Lond B Biol Sci, in press.

Borst JGG, Helmchen F, Sakmann B (1995) Pre- and postsynaptic whole-cell recordings in the medial nucleus of the trapezoid body of the rat. J Physiol (Lond) 489:825-840.

Brose N, Petrenko AG, Südhof TC, Jahn R (1992) Synaptotagmin: a calcium sensor on the synaptic vesicle surface. Science 256:1021-1025.

Dodge FA, Rahamimoff R (1967) Co-operative action of calcium ions in transmitter release at the neuromuscular junction. J Physiol (Lond) 193:419-432.

Dunlap K, Luebke JI, Turner TJ (1995) Exocytotic $\mathrm{Ca}^{2+}$ channels in mammalian central neurons. Trends Neurosci 18:89-98.
Grynkiewicz G, Poenie M, Tsien RY (1985) A new generation of $\mathrm{Ca}^{++}$ indicators with greatly improved fluorescence properties. J Biol Chem 260:3440-3450.

Helmchen F, Borst JGG, Sakmann B (1997) Calcium dynamics associated with a single action potential in a CNS presynaptic terminal. Biophys J 72:1458-1471.

Hillyard DR, Monje VD, Mintz I, Bean BP, Nadasdi L, Ramachandran J, Miljanich G, Azimi-Zoonooz A, McIntosh JM, Cruz LJ, Imperial JS, Olivera BM (1992) A new conus peptide ligand for mammalian presynaptic $\mathrm{Ca}^{2+}$ channels. Neuron 9:69-77.

Iwasaki S, Takahashi T (1998) Developmental changes in calcium channel types mediating synaptic transmission in rat auditory brainstem. J Physiol (Lond) 509:419-423.

Katz B (1969) The release of neural transmitter substances. Springfield, IL: Thomas.

McCobb DP, Beam KG (1991) Action potential waveform voltage-clamp commands reveal striking differences in calcium entry via low and high voltage-activated calcium channels. Neuron 7:119-127.

McDonough SI, Swartz KJ, Mintz IM, Boland LM, Bean B (1996) Inhibition of calcium channels in rat central and peripheral neurons by $\omega$-conotoxin MVIIC. J Neurosci 16:2612-2623.

McLean IW, Nakane P (1974) Periodate-lysine-paraformaldehyde fixative for immunocytochemical microscopy. J Histochem Cytochem 22:1077-1083.

Mintz I, Sabatini BL, Regehr WG (1995) Calcium control of transmitter release at a cerebellar synapse. Neuron 15:675-688.

Mochida S, Sheng Z-H, Baker CM, Kobayashi H, Catterall WA (1996) Inhibition of neurotransmission by peptides containing the synaptic protein interaction site of N-type calcium channels. Neuron 17:781-788.

Mori Y, Friedrich T, Kim M-S, Mikami A, Nakai J, Ruth P, Bosse E, Hofmann F, Flockerzi V, Furuichi T, Mikoshiba K, Imoto K, Tanabe T, Numa S (1991) Primary structure and functional expression from complementary cDNA of a brain calcium channel. Nature 350:398-402.

Qian J, Colmers WF, Saggau P (1997) Inhibition of synaptic transmission by neuropeptide $\mathrm{Y}$ in rat hippocampal area CA1: modulation of presynaptic $\mathrm{Ca}^{2+}$ entry. J Neurosci 17:8169-8177.

Reid CA, Bekkers J, Clements JD (1998) N- and P/Q-type $\mathrm{Ca}^{2+}$ channels mediate transmitter release with a similar cooperativity at rat hippocampal autapses. J Neurosci 18:2849-2855.

Rettig J, Sheng Z-H, Kim DK, Hodson CD, Snutch TP, Catterall WA (1996) Isoform-specific interaction of the $\alpha_{1 \mathrm{~A}}$ subunits of brain calcium channels with the presynaptic proteins syntaxin and SNAP-25. Proc Natl Acad Sci USA 93:7363-7368.

Rettig J, Heinemann C, Ashery U, Sheng Z-H, Yokoyama CT, Catterall WA, Neher E (1997) Alteration of calcium dependence of neurotransmitter release by disruption of calcium channel/syntaxin interaction. J Neurosci 17:6647-6656.

Sakurai T, Westenbroek RE, Rettig J, Hell J, Catterall WA (1996) Biochemical properties and subcellular distribution of the BI and rbA isoforms of $\alpha_{1 \mathrm{~A}}$ subunits of brain calcium channels. J Cell Biol 134:511-528.

Scroggs RS, Fox AP (1992) Multiple $\mathrm{Ca}^{2+}$ currents elicited by action potential waveforms in acutely isolated adult rat dorsal root ganglion neurons. J Neurosci 12:1789-1801.

Sheng Z-H, Rettig J, Takahashi M, Catterall WA (1994) Identification of a syntaxin-binding site on N-type calcium channels. Neuron 13:1303-1313.

Starr TVP, Prystay W, Snutch TP (1991) Primary structure of a calcium channel that is highly expressed in rat cerebellum. Proc Natl Acad Sci USA 88:5621-5625.

Takahashi T, Forsythe ID, Tsujimoto T, Barnes-Davies M, Onodera K (1996) Presynaptic calcium current modulation by a metabotropic glutamate receptor. Science 274:594-597.

Tottene A, Moretti A, Pietrobon D (1996) Functional diversity of P-type and R-type calcium channels in rat cerebellar neurons. J Neurosci 16:6353-6363.

Turner TJ, Adams ME, Dunlap K (1993) Multiple $\mathrm{Ca}^{2+}$ channel types coexist to regulate synaptosomal neurotransmitter release. Proc Natl Acad Sci USA 90:9518-9522.

Von Gersdorff H, Schneggenburger R, Weis S, Neher E (1997) Presynaptic depression at a calyx synapse: the small contribution of metabotropic glutamate receptors. J Neurosci 17:8137-8146. 
Westenbroek RE, Hell JW, Warner C, Dubel SJ, Snutch TP, Catterall WA (1992) Biochemical properties and subcellular distribution of an N-type calcium channel $\alpha_{1}$ subunit. Neuron 9:1-20.

Westenbroek RE, Sakurai T, Elliott EM, Hell JW, Starr TVB, Snutch TP, Catterall WA (1995) Immunochemical identification and subcellular distribution of the $\alpha_{1 \mathrm{~A}}$ subunits of brain calcium channels. J Neurosci 15:6403-6418.

Wheeler DB, Randall A, Tsien RW (1996) Changes in action potential alter reliance of excitatory synaptic transmission on multiple types of $\mathrm{Ca}^{2+}$ channels in rat hippocampus. J Neurosci 16:2226-2237.

Wu LG, Saggau P (1994) Pharmacological identification of two types of presynaptic voltage-dependent calcium channels at CA3 to CA1 synapses of the hippocampus. J Neurosci 14:5613-5622.

Wu LG, Saggau P (1997) Presynaptic inhibition of elicited neurotransmitter release. Trends Neurosci 20:204-212.
Wu, LG, Borst, JGG, Sakmann, B (1998) R-type $\mathrm{Ca}^{2+}$ currents evoke transmitter release at a rat central synapse. Proc Natl Acad Sci USA 95:4720-4725.

Yokoyama CT, Westenbroek RE, Hell JW, Soong TW, Snutch TP, Catterall WA (1995) Biochemical properties and subcellular distribution of the neuronal class E calcium channel $\alpha_{1}$ subunit. J Neurosci 15:6419-6432.

Yoshida A, Oho C, Omori A, Kuwahara R, Ito T, Takahashi M (1992) HPC-1 is associated with synaptotagmin and $\omega$-conotoxin receptor. J Biol Chem 267:24925-24928.

Yoshikami D, Bagabaldo Z, Olivera BM (1989) The inhibitory effects of omega-conotoxins on Ca channels and synapses. Ann NY Acad Sci 560:230-248.

Zucker RS (1996) Exocytosis: a molecular and physiological perspective. Neuron 17:1049-1055. 